\title{
Test Research on Mechanical properties of Recycled Fine Aggregate
}

\section{Mortar}

\author{
Li Wang ${ }^{1}$, Yin $\mathrm{Li}^{2}$, Rong Guan ${ }^{3}$ \\ 1.Huanghe Science and Technology College, Zhengzhou, Henan Province 450063; \\ 1.Huanghe Science and Technology College, Zhengzhou, Henan Province 450063; \\ 3.Huanghe Science and Technology College, Zhengzhou, Henan Province 450063
}

Keywords: Recycled aggregate; Recycled fine aggregate mortar; mechanical properties

Abstract: This paper has utilized the recycled fine aggregate generated by Zhenzhou South $4^{\text {th }}$ Ring Road Construction Waste Treatment Plant as the raw material to replace the natural sand. By adopting a new determined method of mortar mix ratio, through the determination of compressive strength of 108 cube mortar test blocks with three different strength grades and four different recycled fine aggregate replacement ratios, this paper has studied the relation between mortar mechanical properties with recycled aggregate category and replacement ratio and researched the influence of recycled fine aggregate with the same replacement ratio on mortar mechanical properties with different strength as well as the influence of recycled fine aggregate with different replacement ratio on the mortar mechanical properties with the same strength, which has provided reference for the reproduction and reuse of construction waste.

CLC: TU528.04; Document code: A; [Article ID]

\section{Introduction}

While driving the economic prosperity, the development of China's construction industry has also generated large quantities of construction waste and caused inestimable burden for the ecological environment. According to incomplete statistics, the waste generated by cities is about 6 billion $\mathrm{t}$ every year, in which, the construction waste is about 2.4 billion $\mathrm{t}$, taking up $40 \%$ of the total city waste ${ }^{[1][2]}$. The vast majority of waste has been directly transported to suburb for open stacking or simple backfilling without any treatment and the raise dust generated from clearing and stacking process is the main source for the hazy weather in China. While endangering the ecological environment, the waste is seizing human being's living space. Therefore, the research on reduction of construction waste emission, recycling and reuse and other key technology have become extremely urgent ${ }^{[3][4]}$. This paper has utilized the recycled fine aggregate generated by Zhenzhou South $4^{\text {th }}$ Ring Road Construction Waste Treatment Plant to replace the natural sand raw materials according to the national standard Sand for Construction and GB/T 14684-2011 and industrial standard Basic Performance Test Method Standard of Building Mortar JGJ70-2009 and carried out determination on the stacking density under drying state and determines the mix ratio of recycled fine aggregate mortar of different recycled fine aggregate replacement blending scheme (the replacement rate is respectively $0 \%, 30 \%, 60 \%$ and 100\%) of different strength grade (M5, M7.5 and M10) and prepare cement mortar and test block by the mix ratio and take test and research of mortar mechanical property after standard condition maintenance. 


\section{Test design}

\section{Raw materials}

Natural fine aggregate: Natural river sand; stacking density of $1577 \mathrm{~kg} / \mathrm{m}^{3}$; medium sand of fineness modulus of 2.95 with good grading;

Recycled fine aggregate: Zhenzhou South $4^{\text {th }}$ Ring Road Construction Waste Treatment Plant; the main raw materials are waste bricks and little amount of waste concrete; particle with grain size less than $4.75 \mathrm{~mm}$ after broken screening; stacking density of $1390 \mathrm{~kg} / \mathrm{m}^{3}$; medium sand of fineness modulus of 3.1, as shown in Figure $1^{[5]}$;

Water: Public water supply

Cement: 32.5-grade complex Portland cement produced by Mengdian Group with density of $3.10 \mathrm{~g} / \mathrm{cm}^{3}$.

\section{Instrument and equipment}

1. Compression testing machine, as shown in Figure 2.

2. Die trial: cubic triple die trial with side length of 70.7, as shown in Figure 3.

3. Electric vibrating bench, tamping bar, scraper, tray, mixing plate, shovel, electronic scales (weighing: $10 \mathrm{~kg}$; sensitive quantity: $0.1 \mathrm{~kg}$ ), etc.

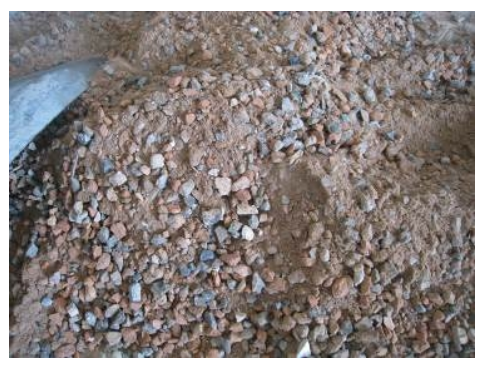

Figure 1 Recycled fine aggregate

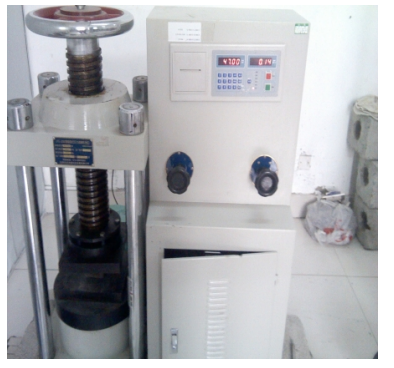

Figure 2 Compression testing machine

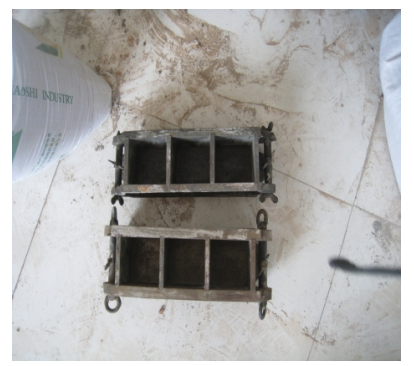

Figure 3 Triple die trial

\section{Determination of mix ratio scheme of recycled fine aggregate mortar}

Blend the recycled fine aggregate with natural fine aggregate with $0 \%, 30 \%, 60 \%$ and $100 \%$ replacement ratio, and measured stacking density under drying state after mixture is as shown in Table 1. It can be seen that the higher the recycled fine aggregate replacement ratio is, the smaller the stacking density of fine aggregate will become. The stacking density of fine aggregate when completely replacing natural mortar is reduced by $11.9 \%$ and it can tell that the stacking density of recycled fine aggregate has no big difference with natural sand. Blend the aggregate of four replacement ratios with cement into three cement mortar with strength grade of M5, M7.5 and M10. According to the industrial standard Masonry Mortar Mix Design Specification JGJ/T98-2010, the water and all powder materials in mortar are used to fill in the gap of aggregate. $1 \mathrm{~m}^{3}$ cement mortar has $1 \mathrm{~m}^{3}$ stacking volume sand, so the sand consumption in $1 \mathrm{~m}^{3}$ cement mortar shall take stacking density value under drying state as the calculation value. As the cement masonry mortar strength for water absorption base level is mainly influenced by cement consumption, the mix ratio when cement mortar of three strength grades choosing recycled fine aggregate with different replacement ratio as fine aggregate can be determined, and the mobility can also be determined as shown in Table 2. It can be seen that the cement consumption of the same grade cement mortar is of the same quantity of water consumption, but the fine aggregate consumption is different; for cement mortar of different strength grades, the water consumption is the same, the cement consumption is different and the aggregate consumption is equal in case of the same replacement ratio; under the condition of the same water consumption, the mortar mobility of the same strength grade will be reduced with the rising recycled aggregate replacement ratio. The mortar of the same replacement rate will be enhanced with the strength grade and the mobility is in down trend on the whole. 
Table 1 Stacking density of fine aggregate when blending recycled aggregate under different replacement ratios $\left(\mathrm{kg} / \mathrm{m}^{3}\right)$

\begin{tabular}{cccc}
\hline $0 \%$ & $30 \%$ & $60 \%$ & $100 \%$ \\
\hline 1577 & 1555 & 1554 & 1390 \\
\hline
\end{tabular}

Table 2 Consumption and cement mortar mix ratio of blended recycled fine aggregate under different replacement ratios

\begin{tabular}{l|c|c|c|c|c}
\hline \multirow{2}{*}{$\begin{array}{c}\text { Test } \\
\text { block }\end{array}$} & $\begin{array}{l}\text { Replacemen } \\
\text { t ratio of } \\
\text { Number }\end{array}$ & \multicolumn{2}{|c|}{ All materials consumption $\left(\mathrm{kg} / \mathrm{m}^{3}\right)$} & Mobility \\
\cline { 2 - 5 } & $\begin{array}{l}\text { recycled } \\
\text { fine }\end{array}$ & Cement & Water & Fine aggregate & Sinking degree \\
& aggregate \% & & & \\
\hline M5a & 0 & 210 & 300 & 1577 & \\
M5b & 30 & 210 & 300 & 1556 & 5.9 \\
M5c & 60 & 210 & 300 & 1554 & 4.1 \\
M5d & 100 & 210 & 300 & 1390 & 3.1 \\
M7.5a & 0 & 280 & 300 & 1577 & 2.1 \\
M7.5b & 30 & 280 & 300 & 1556 & 4.9 \\
M7.5c & 60 & 280 & 300 & 1554 & 2.5 \\
M7.5d & 100 & 280 & 300 & 1390 & 2.0 \\
M10a & 0 & 300 & 300 & 1577 & 4.8 \\
M10b & 30 & 300 & 300 & 1556 & 3.1 \\
M10c & 60 & 300 & 300 & 1554 & 2.1 \\
M10d & 100 & 300 & 300 & 1390 & 1.8 \\
\hline
\end{tabular}

\section{Test results and analysis}

According to the provisions of Test Method Standard of Building Mortar Basic Performance JGJ70-2009, the mortar cube crushing strength shall be calculated according to the average value ${ }^{[6]}$. In this test, every mix ratio shall be made by 9 test blocks in three groups. Of the 9 test blocks, when the error with the average value exceeds $20 \%$, the test block shall be invalid and take the remaining average value as crush resistance actual value. The measured results are as shown in Table 3, Table 4 and Table 5. According to the test block of blending recycled fine aggregate mortar mix ratio under given different replacement ratios, through compression test, it can be seen that all the test blocks can satisfy the designed crush resistance requirements. For the test blocks with the same strength grade, the higher the recycled fine aggregate replacement ratio is, the higher the comprehensive strength average value will become. M5 has the most obvious change. Compared with complete natural aggregate, the complete recycled aggregate strength has been enhanced by 75\%; Compared with complete natural aggregate, M7.5 complete recycled aggregate strength has been enhanced by 43\%; Compared with complete natural aggregate, M10 complete recycled aggregate strength has been enhanced by $26 \%$. 
Table 3 Cube crushing strength of mortar of M5 grade with all replacement ratios

\begin{tabular}{|c|c|c|c|c|c|c|c|c|c|c|c|}
\hline $\begin{array}{c}\text { Test } \\
\text { block } \\
\text { number }\end{array}$ & $\begin{array}{c}\text { Mpa } \\
\text { Cube } \\
\text { crushing } \\
\text { strength } \\
\text { Mpa }\end{array}$ & $\begin{array}{c}\text { Mpa } \\
\text { Average } \\
\text { value } \\
\text { Mpa }\end{array}$ & $\begin{array}{c}\text { Test } \\
\text { block } \\
\text { number }\end{array}$ & $\begin{array}{c}\text { Mpa } \\
\text { Cube } \\
\text { crushing } \\
\text { strength } \\
\text { Mpa }\end{array}$ & $\begin{array}{c}\text { Mpa } \\
\text { Aver } \\
\text { age } \\
\text { value } \\
\text { Mpa }\end{array}$ & $\begin{array}{c}\text { Test } \\
\text { block } \\
\text { number }\end{array}$ & $\begin{array}{c}\text { Mpa } \\
\text { Cube } \\
\text { crushing } \\
\text { strength Mpa }\end{array}$ & $\begin{array}{c}\text { Mpa } \\
\text { Average } \\
\text { value } \\
\text { Mpa }\end{array}$ & $\begin{array}{c}\text { Test } \\
\text { block } \\
\text { number }\end{array}$ & $\begin{array}{c}\text { Mpa } \\
\text { Cue } \\
\text { crushing } \\
\text { strength } \\
\text { Mpa }\end{array}$ & $\begin{array}{c}\text { Mpa } \\
\text { Average } \\
\text { value Mpa }\end{array}$ \\
\hline M5a & $\begin{array}{l}5.8 \\
5.1 \\
4.9 \\
5.4 \\
6.0 \\
5.5 \\
5.9 \\
5.8 \\
4.8\end{array}$ & 5.5 & M5b & $\begin{array}{l}6.7 \\
6.5 \\
6.5 \\
6.8 \\
6.8 \\
7.4 \\
6.7 \\
6.8 \\
6.9\end{array}$ & 6.8 & M5c & $\begin{array}{l}7.8 \\
7.9 \\
8.0 \\
8.2 \\
7.9 \\
7.9 \\
7.8 \\
7.9 \\
7.8\end{array}$ & 7.9 & M5d & $\begin{array}{c}8.7 \\
9.4 \\
9.3 \\
10.2 \\
10.4 \\
9.5 \\
9.0 \\
10.5 \\
9.6\end{array}$ & 9.6 \\
\hline
\end{tabular}

Table 4 Cube crushing strength of mortar of M7.5 grade with all replacement ratios

\begin{tabular}{|c|c|c|c|c|c|c|c|c|c|c|c|}
\hline $\begin{array}{c}\text { Test } \\
\text { block } \\
\text { number }\end{array}$ & $\begin{array}{c}\text { Mpa } \\
\text { Cube } \\
\text { crushing } \\
\text { strength } \\
\text { Mpa }\end{array}$ & $\begin{array}{c}\text { Mpa } \\
\text { Average } \\
\text { value } \\
\text { Mpa }\end{array}$ & $\begin{array}{c}\text { Test } \\
\text { block } \\
\text { number }\end{array}$ & $\begin{array}{c}\text { Mpa } \\
\text { Cube } \\
\text { crushing } \\
\text { strength } \\
\text { Mpa }\end{array}$ & $\begin{array}{c}\text { Mpa } \\
\text { Average } \\
\text { value Mpa }\end{array}$ & $\begin{array}{c}\text { Test } \\
\text { block } \\
\text { number }\end{array}$ & $\begin{array}{c}\text { Mpa } \\
\text { Cube } \\
\text { crushing } \\
\text { strength } \\
\text { Mpa }\end{array}$ & $\begin{array}{c}\text { Mpa } \\
\text { Average } \\
\text { value } \\
\text { Mpa }\end{array}$ & $\begin{array}{c}\text { Test } \\
\text { block } \\
\text { number }\end{array}$ & $\begin{array}{c}\text { Mpa } \\
\text { Cube } \\
\text { crushing } \\
\text { strength } \\
\text { Mpa }\end{array}$ & $\begin{array}{c}\text { Mpa } \\
\text { Average } \\
\text { value } \\
\text { Mpa }\end{array}$ \\
\hline M7.5a & $\begin{array}{l}7.3 \\
6.8 \\
8.1 \\
7.2 \\
7.6 \\
7.7 \\
7.6 \\
7.8 \\
7.2\end{array}$ & 7.5 & M7.5b & $\begin{array}{l}8.6 \\
8.7 \\
8.7 \\
9.0 \\
9.0 \\
8.8 \\
8.5 \\
9.0 \\
8.9\end{array}$ & 8.8 & M7.5c & $\begin{array}{l}9.3 \\
8.6 \\
8.9 \\
9.7 \\
8.4 \\
8.7 \\
8.2 \\
8.5 \\
9.1\end{array}$ & 8.8 & M7.5d & $\begin{array}{l}10.0 \\
11.2 \\
10.2 \\
10.9 \\
10.5 \\
11.4 \\
11.0 \\
10.5 \\
10.8\end{array}$ & 10.7 \\
\hline
\end{tabular}

Table 5 Cube crushing strength of mortar of M10 grade with all replacement ratios

\begin{tabular}{|c|c|c|c|c|c|c|c|c|c|c|c|}
\hline $\begin{array}{c}\text { Test } \\
\text { block } \\
\text { number }\end{array}$ & $\begin{array}{c}\text { Mpa } \\
\text { Cube } \\
\text { crushing } \\
\text { strength } \\
\text { Mpa }\end{array}$ & $\begin{array}{c}\text { Mpa } \\
\text { Average } \\
\text { value } \\
\text { Mpa }\end{array}$ & $\begin{array}{c}\text { Test } \\
\text { block } \\
\text { number }\end{array}$ & $\begin{array}{c}\text { Mpa } \\
\text { Cube } \\
\text { crushing } \\
\text { strength } \\
\text { Mpa }\end{array}$ & $\begin{array}{c}\text { Mpa } \\
\text { Average } \\
\text { value } \\
\text { Mpa }\end{array}$ & $\begin{array}{c}\text { Test } \\
\text { block } \\
\text { number }\end{array}$ & $\begin{array}{c}\text { Mpa } \\
\text { Cube } \\
\text { crushing } \\
\text { strength } \\
\text { Mpa }\end{array}$ & $\begin{array}{c}\text { Mpa } \\
\text { Average } \\
\text { value Mpa }\end{array}$ & $\begin{array}{c}\text { Test } \\
\text { block } \\
\text { number }\end{array}$ & $\begin{array}{c}\text { Mpa } \\
\text { Cube } \\
\text { crushing } \\
\text { strength } \\
\text { Mpa }\end{array}$ & $\begin{array}{c}\text { Mpa } \\
\text { Average } \\
\text { value } \\
\text { Mpa }\end{array}$ \\
\hline M10a & $\begin{array}{c}10.9 \\
9.8 \\
10.3 \\
10.0 \\
9.9 \\
9.0 \\
9.7 \\
10.8 \\
10.5\end{array}$ & 10.1 & M10b & $\begin{array}{c}10.2 \\
10.1 \\
10.5 \\
9.8 \\
10.8 \\
10.4 \\
10.2 \\
10.4 \\
10.5\end{array}$ & 10.3 & M10c & $\begin{array}{l}11.6 \\
11.7 \\
11.9 \\
11.7 \\
11.4 \\
11.9 \\
11.6 \\
11.8 \\
11.7\end{array}$ & 11.7 & M10d & $\begin{array}{l}12.6 \\
12.4 \\
13.0 \\
12.7 \\
13.4 \\
13.5 \\
12.3 \\
12.1 \\
12.7\end{array}$ & 12.7 \\
\hline
\end{tabular}




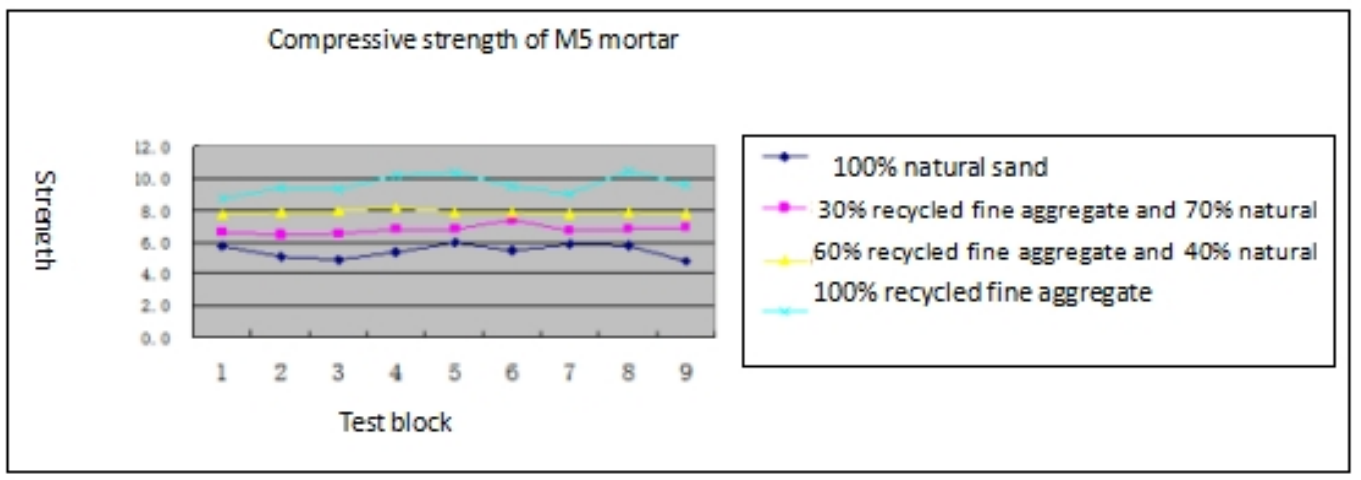

Figure 4 Compressive strength law diagram of M5 recycled fine aggregate cement mortar with different replacement ratio

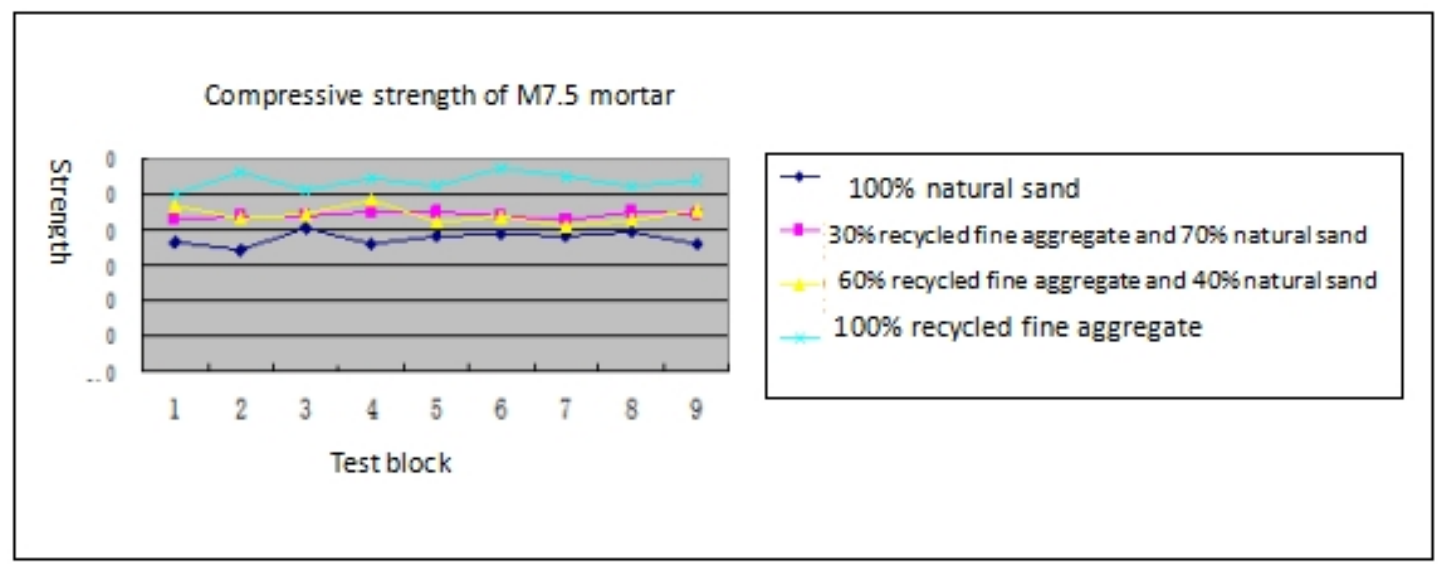

Figure 5 Compressive strength law diagram of M7.5 recycled fine aggregate cement mortar with different replacement ratio

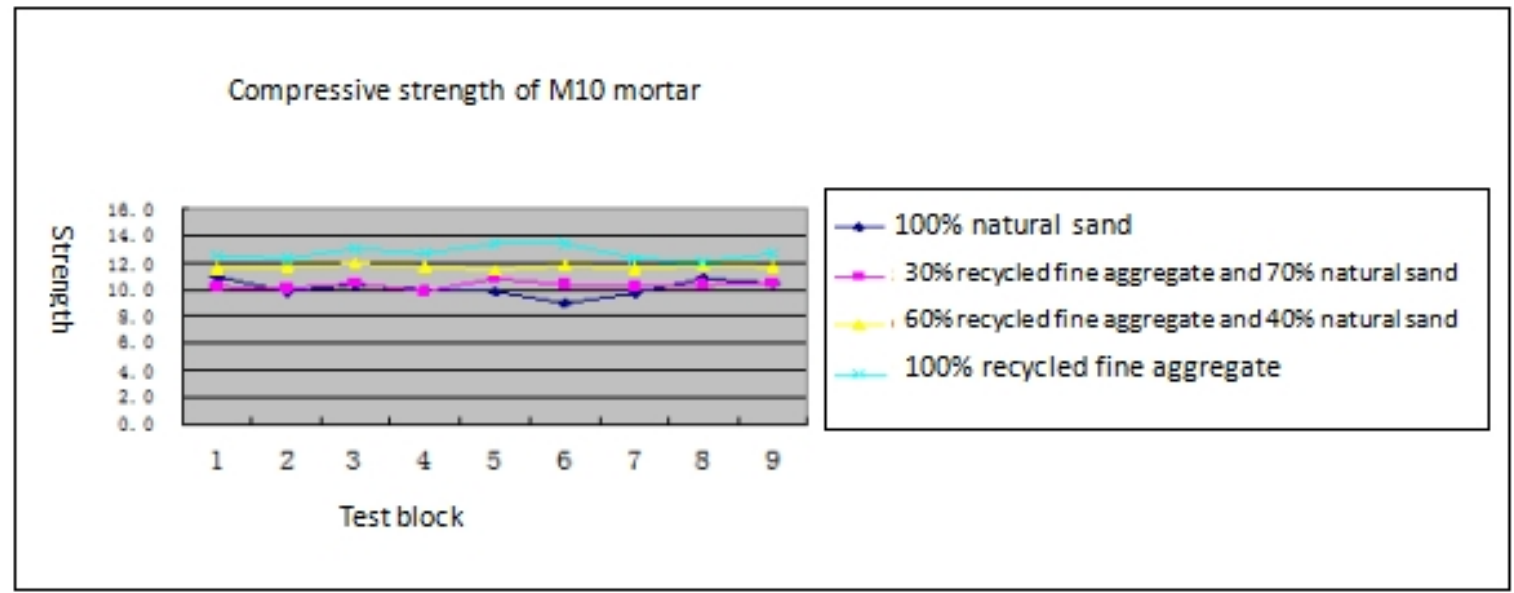

Figure 6 Compressive strength law diagram of M10 recycled fine aggregate cement mortar with different replacement ratio 


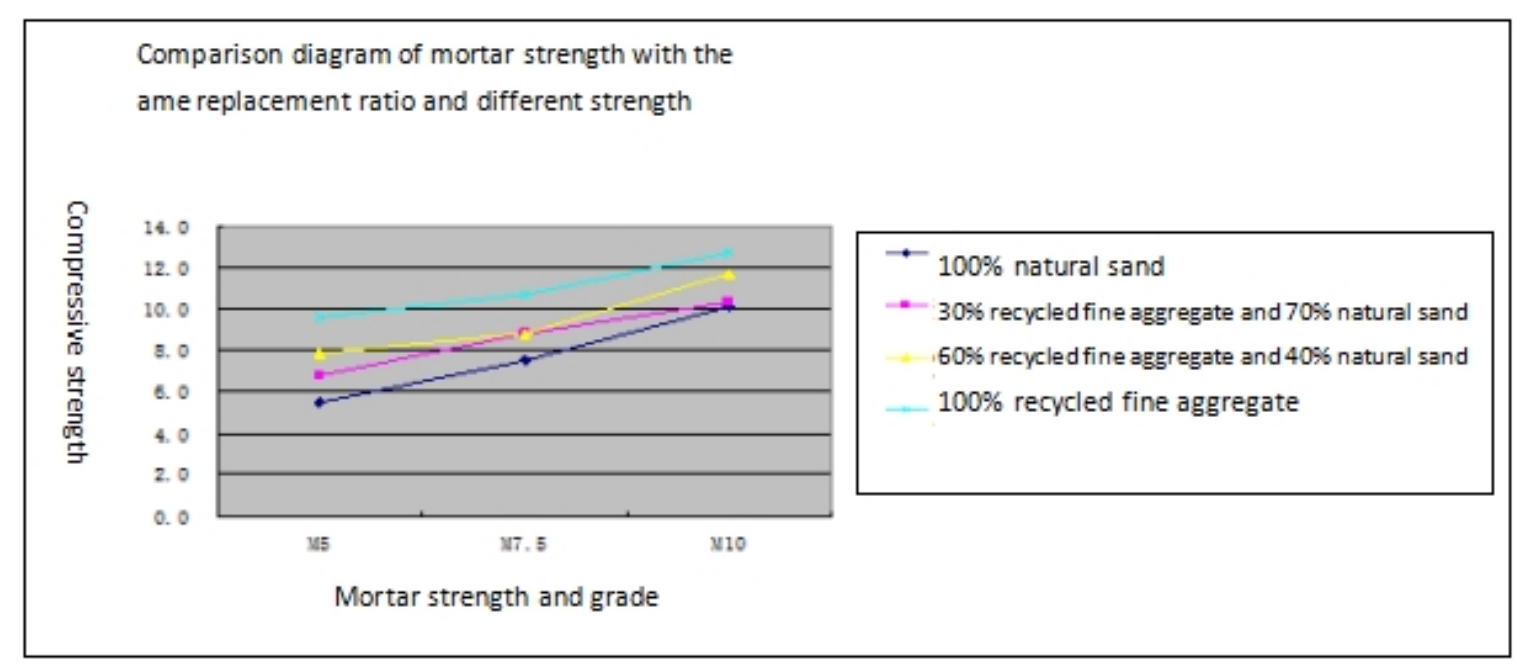

Figure 7 Compressive strength law diagram of recycled fine aggregate cement mortar with the same replacement ratio under different strength grades

We have further analyzed the compressive strength change law of recycled fine aggregate cement mortar with the same strength grade and different replacement ratio and the change law of mechanical performance with the same replacement ratio and different strength grade according to the test results, as shown in Figure 4, Figure 5, Figure 6 and Figure 7. According to the mortar mix ratio method of blending recycled fine aggregate under different replacement ratio, under the conditions of the same strength, cement consumption and water consumption, the cement mortar adopting 100\% recycled aggregate in recycled fine aggregate mortar has the highest strength; with the decrease of recycled aggregate replacement ratio, the compressive strength of cement mortar will decrease but the descent range is decreased successively; the mortar compressive strength with the same replacement ratio will increase with the increase of design strength, which is basically the same with the increase and decrease change law of traditional aggregate strength; under the same design strength, recycled fine aggregate mortar strength will increase with the rising recycled fine aggregate replacement ratio. The cement mortar strength completely adopting natural sand is the lowest and the cement mortar strength completely adopting recycled aggregate is the highest.

\section{Conclusion}

To sum up, the test in this paper adopts the recycled fine aggregate and natural sand with slightly little stacking density ratio, which has led to insignificant difference of stacking density of fine aggregate under different recycled fine aggregate replacement ratio is; under the confirmed mix ratio condition, the cement mortar compressive strength of the same replacement ratio is increased with the increase of design strength; the higher the cement mortar recycled aggregate replacement ratio of the same strength grade will become, and the larger the cement mortar strength will be.

The compressive strength of recycled fine aggregate cement mortar will not be reduced, but will be enhanced instead under the same condition of natural fine aggregate cement mortar water consumption and cement consumption. This discovery will have certain reference value for the production and reutilization of construction waste and ecological environment protection.

\section{References}

[1] Preparation of High-performance Self-compacting Concrete [J]. Building construction, 2007, 29 (12): 958-963. 
[2] Pan Zhisheng, Kou Shicong. Research Progress of Construction Waste Recycled Aggregate Concrete in Hong Kong [J]. Journal of Qingdao Technological University, 2009, 30.

[3] Deng Shouchang, Zhang Xuebing, Luo Yingshe. Status Analysis and Research Prospect of Recycling of Waste Concrete [J]. Concrete, 2006 (11): 20-24.

[4] Liu Qingtao, Cen Guoping, Wang Shuotai. Status and Development of Research Application of Airfield Pavement Recycled Concrete [J]. Subgrade engineering, 2011 (2): 38-40.

[5] Zhuang Guangzhi. Research on the Recycled Aggregate Mortar Performance [D]. Master thesis of Harbin Institute of Technology. Harbin: Harbin Institute of Technology, 2009.

[6] Hao Tong, Zhao Wenlan. Research on Compression of Concrete with Different Recycled Fine Aggregate Replacement Ratios and Drying Shrinkage Test [J]. New building materials, 2011 (2). Project source: Humanities and social sciences of Henan Provincial Department of Education Project number: 2017-ZZJH-336

About the author: Wang Li, master, graduated from College of Civil Engineering of Henan University of Technology; engaged in teaching in Huanghe Science And Technology College; mainly engaged in the teaching and research on building material, building construction and organizational management; published more than ten scientific research education reform papers successively. 